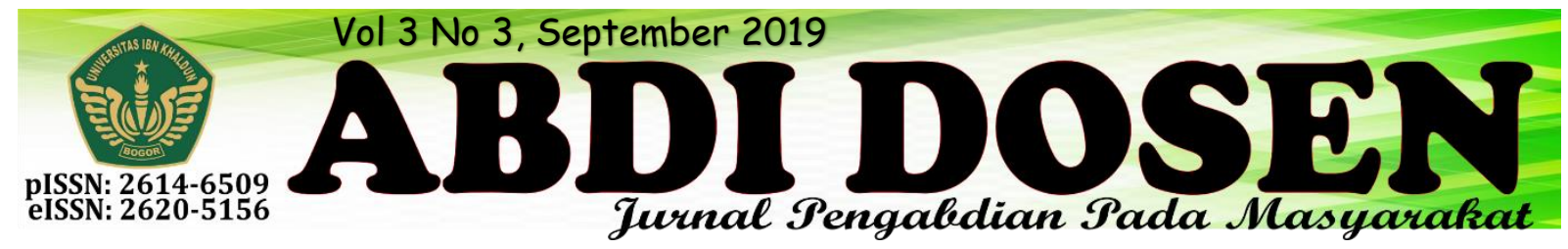

\title{
ANALISIS KEBUTUHAN AIR DAN PEMBANGUNAN SISTEM PENGAIRAN MENGGUNAKAN POMPA AIR DI KAMPUNG CENGAL DESA KARACAK
}

\author{
Gatot Eka Pramono ${ }^{1}$, Rendy Andana ${ }^{2}$ \\ gatot@ft.uika-bogor.ac.id ${ }^{1}$ \\ randyafirfa@gmail.com ${ }^{2}$ \\ Fakultas Teknik Universitas Ibn Khaldun Bogor ${ }^{1}$, Mahasiswa KKN Kelompok 35 Tahun $2018^{2}$
}

\begin{abstract}
ABSTRAK
Kekayaan sumber daya air yang melimpah merupakan anugerah dan kebanggaan yang tak ternilai sehingga patut untuk disyukuri. , namun banyak permasalahan air yang ada di Indonesia seperti masalah yang terjadi di kampung cengal ini adalah krisis air bersih untuk kebutuhan sehari - hari terutama mandi cuci kakus (MCK). Kampung Cengal memiliki kontur tanah perbukitan atau pegunungan sedangkan sumber air yang saat ini digunakan oleh masyarakat berada di bawah pedesaan yaitu sekitar $1000 \mathrm{M}$ atau $1 \mathrm{KM}$ yang saat ini mengalami kekeringan. Pembangunan sistem pengairan bertujuan untuk meningkatkan dan mengembangkan sarana penyediaan air bersih di masyarakat ketika sedang kekeringan. Dengan menggunakan pompa air bermanfaat untuk menyalurkan air dari bawah pedesaan ke rumah warga dengan mudah. Hasil penelitian yang didapat bahwa masyarakat dapat menggunakan air bersih untuk keperluan sehari-hari tanpa mengeluarkan banyak waktu dan tenaga. Air bersih mudah didapatkan melalui system pengaliran menggunakan pompa air.
\end{abstract}

Kata Kunci: kebutuhan air, sistem pengairan, pompa air

\section{PENDAHULUAN}

Indonesia merupakan negara yang kaya akan sumber daya air yang sangat melimpah. Air merupakan kebutuhan yang sangat vital sehingga sangat tergantung terhadap keberadaan air. Tingkat pertumbuhan penduduk yang cukup tinggi membuat kebutuhan air juga akan semakin meningkat pula, pemanfaatan yang sangat bervariasi terhadap keperluan air, juga akan memerlukan kebutuhan air yang cukup tinggi terutama untuk kebutuhan sehari hari.

Prasarana air bersih merupakan salah satu hal yang penting untuk dikaji mengingat air merupakan kebutuhan pokok yang selalu di konsumsi oleh masyarakat dan juga berpengaruh besar pada kelancaran aktivitas masyarakat tersebut. Menurut Thuram (1995), terpenuhinya kebutuhan akan air bersih merupakan kunci utama bagi perkembangan suatu kegiatan dan menjadi elemen penting bagi keberlanjutan suatu produktivitas perekonomian.

Penyediaan air bersih untuk masyarakat di Indonesia masih dihadapkan pada beberapa permasalahan yang cukup kompleks dan sampai saat ini belum dapat diatasi sepenuhnya. Salah satu masalah yang masih dihadapi dalam masyarakat desa karacak kampung cengal pada beberapa wilayah mengalami kesulitan 
untuk mendapatkan air bersih yang sehat dan berkualitas serta kontinu mengalir. Hal ini disebabkan karena kampung cengal memiliki kontur tanah perbukitan atau pegunungan sedangkan sumber air yang saat ini digunakan oleh masyarakat berada di bawah pedesaan, masyarakat membutuhkan banyak waktu dan tenaga untuk mendapatkan air bersih itu sendiri.

Kebutuhan akan air tidak selamanya terpenuhi oleh sumber daya air yang ada pada saat diperlukan. Oleh karenanya diperlukan tampungan untuk menyimpan kelebihan air pada saat kelebihan dan menyalurkannya pada waktu diperlukan. Salah satu bentuk tampungan tersebut adalah waduk. Dimana fungsinya menampung kelebihan air pada musim hujan dan menyalurkan pada musim kemarau. Adanya waduk merubah pola aliran sedemikian rupa sehingga lebih bermanfaat bagi manusia dan lingkungannya. Dalam pengelolaan sumber daya air yang terbatas, dimana terjadi kekurangan untuk pemenuhan kebutuhan air irigasi dan air baku, maka deikehendaki cara operasi yang dapat memperkecil kekurangan tersebut.

Irigasi merupakan salah satu dari aspek yang dikenal sebagai aspek-aspek dalam pengembangan eilayah sungai yaitu:pengendalian banjir, irigasi, pembangkit tenaga listrik, navigasi, penyediaan air bersih, air kota dan air industry, pengelolaan daerah aliran sungai, rekreasi, perikanan darat dan perlindungan satwa liar, penanggulangan pencemaran, pengendalian gulma air, drainase, pengendalian sedimen, pengendalian salinitas, penanggulangan kekeringan dan pengembangan air tanah.

Pompa adalah suatu peralatan mekanik yang digerakan oleh tenaga mesin yang digunakan untuk memindahkan cairan dari suatu tempat lain, dimana cairan tersebut hanya mengalir apabila terdapat perbadaan tekanan. Pompa juga dapat diartikan untuk memindahkan energy pemutar atau penggerak ke cairan ke bejana yang bertekanan yang lebih tinggi. Selain dapat memindahkan cairan pompa juga berfungsi untuk meningkatkan kecepatan, tekanan dan ketinggian cairan.

Berdasarkan keinginan masyarakat untuk mendapatkan air bersih yang sehat dan berkualitas serta kontinu mengalir maka perlu dilakukan pemasangan pompa air di desa karacak kampung cengal. Oleh sebab itu dalam kesempatan ini akan dicoba dibahas mengenai bebearapa hal yang perlu diperhatikan dalam pembangunan sistem pengairan menggunakan pompa air.

\section{Kerangka Teori}

Kebutuhan air adalah banyaknya air yang dibutuhkan untuk keperluan rumah tangga, industri, penggelontoran kota dan lain-lain. Prioritas kebutuhan air meliputi kebutuhan air domestik, industri, pelayanan umum dan kebutuh air untuk mengganti kebocoran( moegijantoro,1995).

Kebutuhan akan air dikategorikan dalam kebutuhan air domestik dan non domestik. Kebutuhan air domestik adalah kebutuhan air yang digunakan untuk keperluan rumah tangga yaitu untuk keperluan minum, masak, mandi, mencuci pakaian serta keperluan lainnya, sedangkan kebutuhan air non domestik digunakan untuk kantor, tempat ibadah, niaga, dan lain-lain.

Sistem pengairan mengandung arti memanfaatkan dan menambah sumber air dalam tingkat tersedia bagi kehidupan tanaman. Apabila air terdapat berlebihan dalam tanah maka perlu dilakukan pembuangan (drainase). Agar tidak mengganggu kehidupan tanaman. Pengairan juga bias disebut dengan irigasi, 
yaitu suatu usaha mendatangkan air dengan membuat bangunan dan saluran-saluran untuk ke sawah-sawah atau lading-ladang dengan cara teratur dan membuang air yang tidak diperlukan lagi, setelah air itu dipergunakan dengan sebaik-baiknya.

Sedangkan dalam arti khusus pengairan adalah suatu usaha untuk mengatur dan memanfaatkan air yang tersedia baik di sungai ataupun di sumber lain, dengan menggunakan jaringanjaringan irigasi untuk kepentingan pengairan. Jaringan irigasi tersebut meliputi antara lain:

1. Saluran-saluran dan bangunanbangunan untuk menyadap air dari suatu sumber air.

2. Saluran-saluran dan bangunanbangunan pelengkap untuk mengalirkan dan membagi air ke lahan pertanian.

3. Saluran-saluran dan bangunanbangunan pelengkap untuk menunjang terlaksananya irigasi.

Sebagai sumber pengairan, air dapat dibagi menjadi tiga golongan:

1. Mata air, yaitu air yang terdapat didalam tanah, seperti air sumur, air artesis dan air tanah. Air tersebut banyak mengandung zat terlarut sehingga mineral bahan makan tanaman sangat kuran dan pada umumnya konstan.

2. Air sungai, yaitu air yang terdapat di atas permukaan tanah. Air tersebut banyak mengandung lumpur yang mengandung mineral sebagai bahan makan tanaman, sehingga sangat baik untuk pemupukan dan juga suhunya lebih rendah daripada suhu atmosfer. Air sungai ini berasal dari dua macam sungai, yaitu sungai kecil yang debitnya berubah-ubah dan sungai besar.

3. Air waduk, yaitu air yang terdapat di permukaan tanah juga seperti pada air sungai. Tetapi air waduk sedikit mengandung lumpur, sedangkan zat terlarutnya sama banyaknya dengan air sungai. Air waduk disini dapat berasal dari dua macam waduk yaitu waduk alam dan waduk buatan manusia.

Adapun jenis-jenis irigasi yaitu:

1. Irigasi permukaan, merupakan system irigasi yang mengambil air langsung di sungai melalui bangunan bending maupun melalui bangunan pengambilan bebas kemudian air irigasi dialirkan secara gravitasi melalui saluran sampai ke lahan pertanian.

2. Irigasi local, system ini air didistribusikan dengan cara pipanisasi. Disini juga berlaku gravitasi dimana lahan yang tinggi mendapat air lebih. Namun air yang disalurkan hanya terbatas sekali atau secara local.

3. Irigasi dengan penyemprotan, penyemprotan biasanya dipakai penyemprotan air atau sprinkler. Air yang disemprotkan akan seperti kabut, sehingga tanaman mendapat air dari atas, dau akan basah lebih dahulu, kemudian menetes ke akar.

4. Irigasi tradisional dengan ember, disini diperlukan tenaga kerja yang banyak. Disamping itu juga pemborosan tenaga yang harus membawa ember.

5. Irigasi pompa air, air diambil dari sumur dalam dan dinaikan melalui pompa air, kemudian dialirkan dengan berbagai cara, misalnya dengan pipa atau saluran. Pada musim kemarau irigasi ini dapat terus mengairi sawah.

6. Irigasi tanah kering, dilahan kering, air sangat langka dan pemanfaatannya harus efisien. Jumlah air irigasi yang diberikan ditetapkan berdasarkan kebutuhan tanaman, kemampuan tanah memegang air, serta sarana irigasi yang tersedia. 
Pada sistem air bersih, penyediaan air harus dapat mecapai daerah distribusi dengan debit, tekanan dan kuantitas yang cukup dengan kualitas air sesuai standaar/higienis. Oleh karena itu perencanaan penyediaan air bersih harus dapat memenuhi jumlah yang

\section{METODE PENELITIAN}

Metode perencanaan adalah tata cara atau urutan kerja suatu perhitungan perencanaan untuk mendapatkan hasil perencanaan instalasi air bersih. Langkah awal dari penelitian adalah survey pendahuluan dan pengumpulan data primer,yaitu:

1. Kondisi fisik sumber air bersih dan merancang bangunan sarana air bersih.

2. Hasil wawancara masyarakat kampung cengal

- Metode pengumpulan data yang digunakan yaitu:

a. Metode analisis, untuk analisa rancangan bangunan sarana air bersih berbasis partisipasi masyarakat digunakan analisis survey yaitu pengumpulan data, menghitung debit air baku, menghitung kebersihan air bersih pada masyarakat, menentukan diameter pipa, dan analisis data dibuat dibuat suatu rancangan bangunan sarana air bersih menurut kebutuhan desa. cukup,higenis, teknis yang optimal dan ekonomis. Dalam perencanaan system penyediaan air bersih suatu bangunan, kebutuhan air bersih tergantung dari fungsi kegunaan bangunan, jumlah peralatan saniter dan jumlah penghuninya.

b. Metode wawancara yaitu suatu kegiatan dilakukan untuk mendapatkan informasi secara langsung dengan mengungkapkan pertanyaan-pertanyaan pada para responden, dan kegiatannya dilakukan secara lisan.

- Waktu dan tempat penelitian

Waktu penelitian dilaksanakan sebanyak 2 kali, satu kali melihat kondisi aliran air pada tanggal 17 agustus 2018 dan pemasangan pipa air pada tanggal 29 agustus 2018. Tempat pelaksanaan pemasangan pipa di kebun sekitar desa karacak kampung cengal bogor .

- Teknis analisis data

Analisis data adalah proses pengorganisasian dan pengurutan data ke dalam pola, kategori, dan satuan urai dasar. Tujuan analisis data untuk menyederhanakan data ke dalam bentuk yang mudah dibaca dan di implementasikan. 


\section{HASIL DAN PEMBAHASAN}

Air bersih sangat diperlukan oleh kalangan penduduk sebagai salah satu sumber kelangsungan hidup, seperti halnya di kampung cengal. Kampung Cengal terdiri dari $1 \mathrm{RW}$ dan $5 \mathrm{RT}$ yang hampir semua mengalami krisis air bersih. Serta air yang dibutuhkan dalam satu keluarga (dengan 2 orang anak) sekitar 500 sampai $650 \mathrm{~L}^{3}$. Perencanaan yang matang diperlukan dalam pengelolan irigasi yang berkelanjutan. Perencaan ini mengkaji beberapa aspek yang akan dilibatkan untuk menentukan kelayakan dari pompanisasi. Hal ini yang perlu diperhatikan adalah biaya yang akan dikeluarkan, manfaat yang diperoleh serta umur ekonomis dari peralatan yang digunakan. Pertumbuhan kebutuhan air bersih harus diperhitungkan dengan baik begitu pula dengan ketersediaan air dari sumber-sumber sumur dalam yang ada.

Analisis kebutuhan air irigasi merupakan salah satu tahap penting yang diperlukan dalam perencanaan dan pengelolaan sistern irigasi. Kebutuhan air tanaman didefinisikan sebagai jumlah air yang dibutuhkan oleh tanaman pada suatu periode untuk dapat tumbuh dan produksi secara normal. Sehingga kebutuhan air dapat dirumuskan sebagai berikut (Sudjarwadi 1990) :

$$
\mathrm{KAI}=\mathrm{ET}+\mathrm{KA}+\mathrm{KK}
$$

Dengan,

$\mathrm{KAI}=$ kebutuhan air irigasi

$\mathrm{ET}=$ Evapotranspirasi

$\mathrm{KA}=$ kehilangan air

$\mathrm{KK}=$ kebutuhan khusus

Cara kerja pompa air pada dasarnya sangat sederhana, yaitu menghisap air dari tempat yang lebih rendah dan mendorong air tersebut ke tempat yang tinggi atau penampung air. Setiap pompa air dilengkapi dengan peralatan otomatis yang berguna untuk memudahkan kita pada saat pengoperasian dan tidak memerlukan aktifitas menghidupkan ataupun mematikan pompa, sebab sudah ada sensor otomatis yang bekerja berdasarkan tekanan yang terdapat pada pipa atau saluran air pada keluaran pompa.

Pada mesin pompa air ada saluran hisap dan ada saluran buang, alat otomatis atau sensornya menggunakan sensor tekanan atau disebut juga Pressure Switch dan dipasang pada tabung pada saluran keluaran pompa. Ketika pompa dihidupkan atau dihubungkan dengan listrik, maka pompa akan berputar sehingga di bagian dalam pompa terjadi vaccum karena adanya perbedaan tekanan, sehingga air yang ada didalam tanah akan terhisap naik.

Ketika mesin aktif, rotor pun berputar bersama dengan baling-baling. Gerakan baling-baling dibatasi oleh cincin kam dan mengalirkan air dari lubang hisap atau yang besar ke lubang tekan atau yang kecil dan semua kran air yang ada di rumah tertutup maka pada saluran keluaran pompa akan timbul tekanan yang cukup besar. Ketika tekanan yang dihasilkan melebihi tekan set yang ada pada sensor, maka sensor akan bekerja dan pompa air akan mati seketika, pompa air akan hidup lagi apabila ada salah satu kran air terbuka disebabkan tekanan air sudah turun.

Pemberdayaan masyarakat dalam pengelolaan air bersih di wilayah penelitian dapat dilakukan dengan cara:

1. Penyuluhan dan pelatihan secara berkala perlu dilakukan untuk meningkatkan pemahaman masyarakat terhadap peran dan fungsinya dalam pengelolaan sarana air bersih ini baik bengunanya, maupun rumah masingmasing. 
2. Mengaktifkan kembali swadaya masyarakat untuk menjaga bangunan sarana air bersih baik bangunan penangkap air, bak penampungan, bak pembagi.

3. Melakukan musyawarah kepada masyarakat untuk pembagian peran dan tanggungjawab pemeliharaan sarana air bersih.

\section{KESIMPULAN}

Kesimpulan yang diperoleh dari penelitian ini Melalu rancangan bangunan sarana air bersih ini masyarakat telah mempunyai panduan atau konsep dalam

\section{DAFTAR PUSTAKA}

https://www.ilmutekniksipil.com/bangunan -air/ilmu-pengairan

Mugijantoro, Air Untuk Kehidupan Manusia, 1995, Majalah Air Minum, edisi No 85.

Maleong lexy. Metodologi penelitian kualitatis.2011, Bandung: Remaja Rosda Karya.
Dengan dilakukannya analisis kebutuhan air bersih dan pembangunan sistem pengairan di kampung cengal, sekarang masyarakat dapat menggunakan air bersih untuk kebutuhan sehari-hari dengan mudah tanpa harus menguras waktu dan tenaga.

membangun arana air bersih untuk memenuhi kebutuhan masyarakat kampong cengal.

Idaman, S.N. Masalah dan Srategi Penyediaan Air Bersih, 2000, Jakarta: Renika Cipta.

Ahmad Santoso, Sistem Plambing dan Sanitasi, 2007, Jakarta: Dinas Pendidikan 